\title{
Lactating performance of West African dwarf does fed dietary levels of boiled rubber seed meal based diets
}

${ }^{1}$ Udo, M. D., ${ }^{2}$ Ahamefule, F. O., ${ }^{2}$ Ibeawuchi, J. A. and ${ }^{1}$ Ekpo, J. S.

${ }^{\prime}$ Department of Animal Sc. Akwa Ibom State University, Obio Akpa Campus, Akwa Ibom

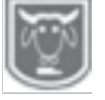

Abstract
State, Nigeria.

${ }^{2}$ Department of Animal Production and Livestock Management, MOUAU, Umudike, Abia State, Nigeria.

Animal milk has been an outstanding balanced food for man, and a very good source of protein to man. The bulk of milk consumed in Nigeria is imported. An experiment was conducted with twelve lactating West African dwarf does that were at their second parity using graded levels $(0 \%, 10 \%, 20 \%$ and $30 \%)$ of boiled rubber seed meal to investigate their colostrum and normal milk yield and proximate compositions. The rubber seeds were boiled for 30 minutes, dehulled and dried for three days before being milled and used alongside cassava peels, brewer dried grain, palm kernel cake, bone meal and salt to formulate boiled rubber seed meal based diet. The twelve does were individually housed in a well ventilated cement floored pen with wood shaving as bedding material. $1 \mathrm{~kg}$ of the concentrate diet designated as $A, B, C$ and $D$ were randomly assigned to the four treatment groups. The diets were supplied to the does in wooden feeding trough at 0800 hour in the morning while $2 \mathrm{~kg}$ of Panicum maximum was fed to the does by 1400 hours daily. The does were fed with the concentrate diet at the beginning of their last month of pregnancy and through to the $55^{\text {th }}$ day of post-partum. The kids were weighed on their first day of parturition. Colostrum was collected, weighed and samples stored at $-5^{\circ} \mathrm{C}$ in a refrigerator for constituent analysis, but certain sample of colostrum was also used for lactose analysis daily. The lactating does were hand milked once in the morning and a constant 0.6596 was used as a weighing factor on the morning yield using $S=M+0.6596 M$ as correcting factor. Prior to each day milking, kids were separated from the dams from 1800 hour and fed with the aid of feeding bottle. Colostrum and normal milk samples were analysed for crude protein, (Nx6.38), lactose, total solids, solid-not-fat, butterfat, ash and energy. Lactose was analysed using Marier and Boulet procedures. Butterfat was determined by Kjeldahl and Markhaps apparatus while solid-not-fat was obtained from the differences between butterfat and total solids. Energy was computed using multiple regression equation. AOAC method was used to determine the proximate composition of the experimental diets. There was no significant differences $(P<0.05)$ among the treatment groups $(A, B, C, D)$ in their colostrum yield $(66.75,77.69$, 73.67 and 69.33), total solids (17.24, 17.39, 16.47 and 16.99) and butterfat (4.90, 4.90, 4.88 and 4.85) respectively. But $C P, S N F$, lactose, ash and energy had significant differences $(P>0.05)$ in their colostrum with treatment $D$ having superior value $(6.87 \%)$ compared to $A$ $(6.58 \%), B(6.50 \%)$ and $C(6.44 \%)$. The CP value increases as the BRSM increases in diet. All parameters in normal milk were statistically similar in their values, but treatment $B(10 \%$ BRSM) expressed superior value among the treatment groups. In this study, 30\%BRSM promoted least milk yield while 10\%BRSM promoted highest milk yield. Therefore, $10 \%$ inclusion level of BRSM is recommended for lactating WAD does for high milk yield.

Keywords: Lactating, boiled rubber seed, colostrum, alternative feed source, correlation, West African dwarfdoes 


\section{West African dwarf does fed dietary levels of boiled rubber seed meal based diets}

\section{Introduction}

One of the comprehensive/balance food/feed for man and livestock is milk. Does as small ruminants are noted for their milk production which is relative to their size, breed, type, environment, feed and feeding regime etc. both quantity and quality of feed eaten by lactating doe is one of the major factors affecting their milk yield particularly during the dry season of when there is low quality and quantity of forage materials (Udo, 2016). It has been reported that goats on natural pasture in Nigeria cannot meet their energy and protein requirements (Adebowale, 1981). However, providing concentrate feed as supplement to forage during dry season improves milk yields (Prasanpanich et el., 2002). According to Polan et al. (1985) milk yields of Holstein cows supplemented with brewer's grain was better in quality and quantity than soybean-supplemented group. Leacaena supplementation also increased dry-matter intake, milk yield and live weight of crossbreed dairy cows (Muinga et el., 1992), while Gliricidia sepium also improved milk yield in cows (Perdock et al, 1982). The estimated population 53.8 million of goats in Nigeria is significant enough to contribute immensely to the country dairy industry, however, there is poor or no record of their production. Adamu et al. (2010) reported that nutrition has been one of the major factors responsible for poor performance by WAD goats. However, in order to improve its milk production, there is the need to provide a good feeding regime (Ahamefule et al., 2007). Goat milk is known to be better than other milks. It is rich in glycerol ethers which are important for nursing infants, having higher digestibility than cow or human milk, distinct alkalinity, higher buffering capacity, and certain therapeutic values in human medicine and nutrition (Devendra and Burns, 1983). According to Amrein-Boyes (2009), it has small, well-emulsified fat globules and; dairy goats in their prime (around $3^{\text {rd }}$ or $4^{\text {th }}$ lactation cycle) produce on the average 2.7$3.6 \mathrm{~kg}$ of milk production daily, it has yellow "beta-carotene" a precursor of vitamin A. Rubber seeds are high in CP (21-28), fibre (above 18\%) and energy (2-4.7\%). The seeds are also good source of energy, calcium, valine, isoleucine, phenylalanine and tyrosine; and the seed cake contains; 35.1 CP, 12.6 EE, 7.1. CF, 34.8 NFE, 10.5 ash, 18.6 DCP, 66 TDN, 1.0 Ca, 0.8 P and $9 \mathrm{mg} / 100$ of HCN (Njwe, et al., 1988). Decorticated rubber seed meal contains $\mathrm{ME} / \mathrm{Kcal} / \mathrm{kg}$ of $4280, \mathrm{CP} 32.98 \% \mathrm{EE}$, $10.12 \%$ Ash, 6.21\%, CF $4.20 \%$. Antinutritional factor present are Tannin $4.23 \mathrm{mg}$, Trypsin Inhibitor 0.432 units (trace) Amylase $1.14 / \mathrm{kg}$, cyanogenic glucose-not detected (Eneh, 1998). Rubber seeds had been used to evaluate the performance of animals like; poultry (Nouke and Endeley, 2001), rat (Yeong et al., 1981), pig (Babatunde et al., 1990) and sheep (Njwe et al., 1988) and all the results showed that rubber seeds were saveas feed source for the above animals however, there is scarcity of trials using boiled rubber seed meal to feed goat. Hence, the aim of this work is to investigate colostrums yield, milk yield and proximate composition of colostrum and normal milk of West African dwarf goats fed boiled rubber seed meal based diet.

\section{Materials and methods Experimental site}

The experiment was conducted at the goat Unit of the Teaching and Research Farm, Michael Okpara University of Agriculture Umudike, Nigeria. Umudike is located between Latitude $05^{0} 29^{1}$ North of the Equator and Longitude $07^{0} 33^{1}$ East of the Greenwich Meridian. It is a warm humid place with an average ambient temperature of $25^{\circ} \mathrm{C}$ and annual rain fall of $2200 \mathrm{~mm}$ distributed over eight months (March- 
November).

\section{Experimental animals and management} Twelve (12) lactating does of the Goats Unit of the Teaching and Research Farm of Michael Okpara University of Agriculture were used for the experiment. The lactating does were in their second parity. They were randomly divided into four groups of three does per treatment group with a doe being a replicate in its group. The lactating doe were housed in an individual ventilated cement floored pen measuring $1.8 \mathrm{mx} 1.7 \mathrm{~m}$. Wood shaving was used as bedding material. In the first four (4) months of pregnancy, the animals were fed mainly on forage sward; but in the last months (last four weeks) of pregnancy, each in-doe received $1 \mathrm{~kg}$ of designated concentrate diet in the morning
(08:00 hour) and $2 \mathrm{~kg}$ of guinea grass (Panicum maximum) in the afternoon (14:00 hour). This feeding regime continued through the parturition into the $55^{\text {th }}$ day of lactation for each doe. Prior to the trial, the animals were subjected to routine spraying and deworming. They were also vaccinated against Peste des petits de ruminant (PPR) a viral disease of ruminant endemic in the environment.

\section{Experimental diets}

One kilogramme of raw rubber seeds were boiled for 30 minutes discarded, dried, dehulled, milled and used to formulate experimental diets such that boiled rubber seed meal replaced brewer dried grain meal at $0 \%, 10 \%, 20 \%$ and $30 \%$ respectively. Clean water was offered at ad libitum.

Table 1: Composition and proximate assay of experimental diets containing various inclusion levels of boiled rubber (Hevea brasiliensis) seed meal

\begin{tabular}{|c|c|c|c|c|}
\hline \multirow[b]{2}{*}{ Ingredients } & \multicolumn{4}{|c|}{ DIETS } \\
\hline & $\mathbf{A}$ & B & C & D \\
\hline Cassava peels & 30.5 & 30.5 & 30.5 & 30.5 \\
\hline BRSM & 0 & 10 & 20 & 30 \\
\hline Brewer dried grain & 50 & 40 & 30 & 20 \\
\hline Palm kernel cake & 17 & 17 & 17 & 17 \\
\hline Bone meal & 2 & 2 & 2 & 2 \\
\hline Salt & 0.5 & 0.5 & 0.5 & 0.5 \\
\hline Total & 100 & 100 & 100 & 100 \\
\hline \multicolumn{5}{|c|}{ Chemical composition (\% DM) } \\
\hline Dry matter & 89.80 & 91.96 & 88.27 & 87.02 \\
\hline Crude protein & 14.50 & 14.06 & 15.40 & 15.82 \\
\hline Crude fibre & 18.12 & 17.65 & 17.07 & 16.82 \\
\hline Ether extract & 4.10 & 4.90 & 4.92 & 4.92 \\
\hline Ash & 5.94 & 6.26 & 6.37 & 6.73 \\
\hline $\mathrm{N}$-free extract & 47.44 & 47.59 & 44.49 & 42.73 \\
\hline GE (Kcal/g)* & 1.68 & 1.77 & 1.66 & 1.64 \\
\hline
\end{tabular}

*Caculated, $\mathrm{BRSM}=\mathrm{Boiled}$ rubber seed meal, $\mathrm{A}=0 \%$ boiled rubber seed meal, $\mathrm{B}=10 \%$ boiled rubber seed meal, $C=20 \%$ boiled rubber seed meal and $D=30 \%$ boiled rubber seed meal

\section{Kid's management}

Birth weights were recorded immediately after parturition for each kid. Colostrum yield was quantified as the difference between the weight of kids before and after suckling. New born kids were allowed to freely suckle their dams except on the eve of the day proceeding each sampling day.

\section{Milk sampling}

Colostrum samples were taken from each lactating doe on the 1-3 days of postpartum. Lactose content of daily drawn colostrums 
West African dwarf does fed dietary levels of boiled rubber seed meal based diets

samples were analysed immediately; thereafter samples for each animal were bulked and subsequently analysed for protein, butterfat, solid-not-fat, total solids, energy and ash. The bulked colostrums samples were stored in a refrigerator at $-5^{\circ} \mathrm{C}$ until required for analysis. Milk sample collection commenced on the $10^{\text {th }}$ day and terminated on the $55^{\text {th }}$ day post-partum. Samples from daily milk yield for each doe was analysed for lactose content before being bulked and analysed weekly for crude protein, butterfat, solid-not-fat, total solids, energy and ash. The bulked samples were stored in a refrigerator at $-5^{\circ} \mathrm{C}$ until required for analysis. The weekly milk production was a summation of the 7-day milk yield per doe for the week. The weekly lactose contents of milk of does were determined as average of daily lactose determinations.

\section{Milk measurement}

The lactating does were hand milked once in the morning. The total volume of milk yield per day was recorded as the morning daily yield of the doe. The daily milk yield was however established for each doe on the assumption that actual daily production of doe can be met if the animals were milk twice a day. Therefore, based on the concept of fixed yield responses to changing milking frequency (Erdman and Verner, 1995), the constant 0.6596 was used as a weighing factor on the morning milk yield. Each day milk yield was estimated as: $\mathrm{S}=\mathrm{M}+0.6596 \mathrm{M}$. Where, $\mathrm{M}$ is the morning milk yield (once- a day milking). Prior to each day's milking, kids were separated from their dams at 1800 hour proceeding the day of milking. Within this period of separation, kids were fed with the aid of feeding bottle. During milking, the two halves of the udder of lactating does were hand milked daily between 0700 and 0800 hours. The quantity of milk harvested from a doe was measured using a graduated glass cylinder $(500 \mathrm{ml}$ capacity) and weighed back to the nearest gram on a sensitive laboratory scale. Dams were allowed to nurse their kids in the morning after milking and in the afternoon before separation at 1800 hour daily.

\section{Analytical procedure}

The milk samples and the colostrums were analysed for crude protein (Nx6.38), lactose, total solids, solid-not-fat, butterfat, ash and energy. The solid was determined by drying about $5 \mathrm{~g}$ og milk samples to a constant weight at $105^{\circ} \mathrm{C}$ for 24 hours. Lactose content was determined from fresh samples by the Marier and Boulet (1959) procedure. The butterfat was obtained by the semi-micro distillation method using Kjeldahl and Markhamps apparatus. Solidnot-fat was determined as the difference between total solids and butterfat. Milk energy $\mathrm{Y}(\mathrm{MJ} / \mathrm{kg})$ was computed using the multiple regression equation. $\mathrm{Y}=0.386 \mathrm{~F}+0.205 \mathrm{SNF}-0.236 \quad$ (MAFF, 1984). Where, F and SNF represent percentages of fat and solids-not-fat respectively. Proximate compositions of the experimental diets were determined following AOAC (2000) method.

\section{Statistical analysis}

Data on colostrum, normal milk and milk compositions were subjected to analysis of variance (ANOVA) procedures appropriate for a Completely Randomised Design (Morris 1999). Weekly variations in milk yield and composition were determined for all treatment groups. Significant means were separated using Duncan's Multiple Range Test (Duncan, 1955). Simple linear regressions were used to determine the degree of relationships between milk constituents in goat.

\section{Result and discussion}

The Colostrum yield and composition of does fed graded $(0,10,20,30 \%)$ levels of boiled rubber seed meal are shown in Table 2 . Insignificant differences $(\mathrm{P}>0.05)$ among the treatment groups in total colostrum yield $(66.75,77.679,73.67$ and 69.33$)$ total solids 


\section{Udo, Ahamefule, Ibeawuchi and Ekpo}

(17.24, 17.39, 16.47 and 16.99) and butterfat (4.90, 4.90, 4.88 and 4.85) for treatment A,B,C and D of $0 \%, 10 \%, 20 \%$ and $30 \%$ inclusion level of boiled rubber seed meal were obtained. The similarities in colostrum milk across treatments were an indication that boiled rubber seed meal (BRSM) could enhance colostrum yield even at 30\% inclusion level. However, significant differences $(\mathrm{P}>0.05)$ occurred in protein $(\%)$, solid-not-fat $(\%)$, lactose $(\%)$, ash $(\%)$ and energy $(\mathrm{kcal} / \mathrm{kg})$ components among the treatment groups. The value of protein in colostrum ranged from 6.44 for does fed diet C (20\% BRSM), 6.50 for does on diet B (10\% BRSM), 6.58 for does fed $\operatorname{diet} \mathrm{A}(0 \% \mathrm{BRSM})$ and 6.87 for does on diet D $(30 \%$ BRSM $)$. Diet D (30\% BRSM) promoted more concentration of protein content in colostrum that was significantly different $(\mathrm{P}>0.05)$ from protein content of colostrum from does fed diet A $(0 \%)$, B $(10 \%)$ and C (20\%) BRSM. Colostrum protein of does fed diet $A$ and $B$ were similar $(\mathrm{P}>0.05)$ statistically, and lower to treatment $\mathrm{D}$ but higher than treatment $\mathrm{C}$. The higher protein content in treatment D might be due to of highest inclusion level of BRSM (30\%) in does diets. Daily colostrum yield, total colostrum yield, total solid and butterfat values were statistically similar $(\mathrm{P}>0.05)$ among the treatment groups, with $\mathrm{B}(10 \% \mathrm{BRSM})$ showing highest values in all the parameters; indicating that $10 \%$ boiled rubber seed meal inclusion level enhances yield, best solid-not-fat and butterfat composition. But protein, solidnot-fat, lactose and ash were significantly different (P0.05) in their respective values among the treatment group.

Table 2: Effect of diets on Colostrum yield and composition of West African dwarf does

Treatment diets

\begin{tabular}{llllll}
\hline Parameter & A & B & C & D & SEM \\
\hline Total Colostrum yield (g) & 66.75 & 77.69 & 73.67 & 69.33 & 28.30 \\
Daily Colostrum yield(g) & 22.25 & 25.89 & 24.55 & 23.11 & 3.11 \\
Total solids (\%) & 17.24 & 1739 & 16.47 & 16.99 & 0.01 \\
Butterfat (\%) & 4.90 & 4.90 & 4.88 & 4.85 & 0.05 \\
Protein (Nx6.38) (\%) & $6.58^{\mathrm{b}}$ & $6.500^{\mathrm{b}}$ & $6.440^{\mathrm{c}}$ & $6.87^{\mathrm{a}}$ & 0.01 \\
Solid-not-fat (\%) & $12.34^{\mathrm{b}}$ & $12.48^{\mathrm{a}}$ & $11.59^{\mathrm{d}}$ & $12.14^{\mathrm{c}}$ & 0.01 \\
Lactose (\%) & $1.17^{\mathrm{d}}$ & $1.21^{\mathrm{c}}$ & $1.32^{\mathrm{b}}$ & $1.42^{\mathrm{a}}$ & 0.01 \\
Ash (\%) & $0.78^{\mathrm{d}}$ & $0.81^{\mathrm{c}}$ & $0.93^{\mathrm{a}}$ & $0.89^{\mathrm{b}}$ & 0.01 \\
Energy (Kcal/g) & $4.18^{\mathrm{b}}$ & $4.21^{\mathrm{a}}$ & $4.02^{\mathrm{d}}$ & $4.12^{\mathrm{c}}$ & 0.01 \\
\hline
\end{tabular}

abcd meeaen on the same row with different superscripts differ significantly

$\mathrm{SEM}=$ standard error of the mean

Average milkyield and composition of WAD does fed various boiled rubber seed meal are shown in Table 3. Total yield, average daily yield, total solids, butterfat, crude protein, solid-not-fat, lactose, ash and energy were similar in their values except for treatment B $(10 \%)$ that had relatively higher values for milk yield, daily milk yield, crude protein, lactose and ash. The total milk yield of $2.57-2.94 \mathrm{~kg}$ recorded in this study was higher than the range 1.3$2.33 \mathrm{~kg}$ reported by Ahamefule (2005) for does fed pigeon pea diet, but comparable with $2.58-2.97 \mathrm{~kg}$ obtained by Anya (2012). However, Rai (1980) and Ahamefule (2005) opined that diets that promote weight gain will most times naturally lead to poor milk synthesis and vice versa. This has to do with metabolism pattern and ruminal production of volatile fatty acids; acetate and propionate being precursors to milk synthesis and meat production respectively (Matthewman, 1995 and McDonald et al., 1995). In this study, diet D (30\% BRSM) promoted least $(2.57 \mathrm{~kg})$ milk yield while diet B $(10 \%$ 


\section{West African dwarf does fed dietary levels of boiled rubber seed meal based diets}

BRSM) promoted the highest $(2.94 \mathrm{~kg})$ and this was followed by C (20\% BRSM) and A $(0 \% \mathrm{BRSM})$ in that order. This suggests that more ruminal propionate than acetate probably was produced in does fed diet $\mathrm{D}$ $(30 \%$ BRSM $)$ relative to diet $\mathrm{B}(10 \%$ BRSM), C (20\% BRSM) and A $(0 \%$ BRSM), hence, the characteristically low milk production. However, it could well also be that more ruminal acetate than propionate was produced in goats fed diet B $(10 \%$ BRSM) which result in the higher milk yield recorded for does on diet B. Average daily milk yield (g) followed similar pattern of the total milk yield and values obtained for all treatment groups were consistent for WAD does in similar experiments (Ahamefule, 2005; Ahamefule and Odoemelam, 2006; Anya, 2012).

Milk protein $(\mathrm{Nx} 6.38)$ was not influenced by dietary treatments $(\mathrm{P}<0.05)$. These values: $4.15,4.76,4.27$ and 4.98 for diets $A$, $\mathrm{B}, \mathrm{C}$ and $\mathrm{D}$ respectively were consistent with the values reported by Anya (2012).
Solid-not-fat $(\%)$ concentration in milk did not differ $(\mathrm{P}<0.05)$ significantly among the treatment groups with a value range of 12.10-13.68. These values were consistent with Ahamefule, (2005) and Anya, (2012) who had in their values a range of 12.0013.50 in milk of WAD goats.

Total solids followed similar pattern and consistency. Butterfat was least with does fed diet B (4.45\%). Obviously, there was no significant difference $(\mathrm{P}>0.05)$ among the treatment groups. Values $(4.54,4.45,4.59$ and $4.74 \%$ ) obtained in this study for butterfat compared favourably with the range reported by various workers: 4.10$5.77 \%$ (Ahamefule, et al., 2007), 4.43$5.49 \%$ (Anya, 2012), but lower than 6.9\% reported by Jenness and Juarez (1980). Lactose and ash in milk did not differ significantly $(\mathrm{P}>0.05)$ among the treatment groups and did not follow a definite trend. Milk energy tended to increase relatively as level of inclusion of BRSM increases though not significantly different.

Table 3: Milk yield and composition of lactating WAD does fed dietary levels of boiled rubber seed meal

\begin{tabular}{lccccc}
\hline & \multicolumn{5}{c}{ Treatment diets } \\
\cline { 2 - 5 } Parameter & A(0\%BRSM) & B(10\%BRSM) & C(20\%BRSM) & D(30\%BRSM) & SEM \\
\hline Milk yield (kg) & 2.84 & 2.94 & 2.86 & 2.57 & 53.75 \\
Av. daily yield(g) & 63.20 & 65.31 & 63.53 & 57.11 & 10.81 \\
Total solids (\%) & 16.55 & 17.59 & 17.75 & 18.42 & 1.73 \\
Butterfat (\%) & 4.54 & 4.45 & 4.59 & 4.74 & 0.20 \\
CP (Nx6.38) (\%) & 4.15 & 4.76 & 5.27 & 4.98 & 0.50 \\
Solid-not-fat (\%) & 12.10 & 13.21 & 13.00 & 13.13 .68 & 1.54 \\
Lactose (\%) & 3.86 & 3.95 & 3.84 & 3.92 & 0.25 \\
Ash (\%) & 0.79 & 0.80 & 0.79 & 0.79 & 0.03 \\
Energy (Kcal/g) & 3.99 & 4.18 & 4.20 & 4.39 & 0.30 \\
\hline SEM-Standard
\end{tabular}

$\mathrm{SEM}=$ Standard error of the mean

The relationship between milk yield and milk constituents are shown in Table 4. Milk constituents (Williams et al., 2010) as well as yield (Ibeawuchi, 1985) are generally influenced by dietary regime. Earlier investigations (Jenness, 1980; Ahamefule, 2003; 2004; Anya, 2012) had established relationship between milk yield and constituents. The three authors obtained negative correlations between yield and butterfat and these agreed with the findings of this study. Butterfat (BF) value was lowest in the milk of does fed diet B $(4.45 \%)$ which promoted the highest mean milk yield $(2.94 \mathrm{~kg})$. Ahamefule et al. (2003), Ahamefule (2004) and Anya (2012) reported inverse relationship between total solids and milk yield which was in consonance with the values recorded in this study. Total solids (TS \%) obtained for 


\section{Udo, Ahamefule, Ibeawuchi and Ekpo}

goats fed diet B (10\%BRSM) was least (17.59) when compared with other diets (20\% and 30\%BRSM). Also, TS and BF values were highest in the milk of does fed $30 \%$ BRSM (18.42; 4.74\% respectively) which nonetheless promoted the least milk yield. A strong positive relationship exists between BF and energy (Jenness, 1980), thus, milk high in butterfat percent is expected to be high in energy as well (Ahamefule, 2005). Beside the control diets, this assertion holds for milk energy values obtained from diets B. C. and D $(10 \%, 20 \%, 30 \%$ BRSM $)$. Milk samples from does fed $10 \%$ BRSM had low butterfat content $(4.45 \%)$ and low milk energy $(4.18 \mathrm{MJ} / \mathrm{kg})$. Milk energy is a function of BF and solid-not-fat (Ibeawuchi, 1995) and volume of milk produced (Ahamefule, 2005). The relationship between milk yield (MY) and constituents of goat milk are shown in Table 4. Milk yield was negative but significantly highly correlated with $\mathrm{BF}$ $(r=-0.93 ; \mathrm{P}>0.05) \mathrm{SNF}(\mathrm{r}=-0.89 ; \mathrm{P}>0.05)$, lactose $(\mathrm{r}=-0.90 ; \mathrm{P}>0.05)$ and energy $(\mathrm{r}=$ $0.89 ; \mathrm{P}>0.05)$. It was also negative but poorly significantly correlated with TS $(r=$ $0.50 ; \mathrm{P}<0.05)$ and significantly high $(\mathrm{P}>0.05)$ positive correlations existed between energy and BF ( $\mathrm{r}=0.99)$, lactose and SNF $(r=0.78)$, while the relationships between crude protein (CP) and SNF ( $\mathrm{r}$ $=\mathrm{r} 0.19 ; \mathrm{P}<0.05)$ and between $\mathrm{BF}$ and $\mathrm{CP}(\mathrm{r}=$ $0.14 ; \mathrm{P}<0.05), \mathrm{MY}$ and $\mathrm{CP}(\mathrm{r}=0.17$; $\mathrm{P}<0.05)$ were positive, poor and nonsignificant. However, relationships between MY and SNF, MY and lactose, MY and energy were significant $(\mathrm{P}>0.05)$ and were in agreement with the report of Ahamefule (2005). The positive correlations between BF and TS, CP and TS, energy and TS recorded in this study is in tandem with the observations made by Ahamefule (2005) and Anya (2012).

Table 4: the relationship between milk yield and milk constituents of WAD does

\begin{tabular}{llllll}
\hline Parameter & Regression equation & SE & R2 & r & Sig. \\
\hline MY TS & $\mathrm{Y}=18.94-0.001 \mathrm{x}$ & 0.001 & 0.255 & -0.50 & $\mathrm{~ns}$ \\
MY BF & $\mathrm{Y}=7.53-0.002 \mathrm{x}$ & 0.000 & 0.878 & -0.93 & $* *$ \\
MY CP & $\mathrm{Y}=5.14+0.000 \mathrm{x}$ & 0.001 & 0.029 & 0.17 & $\mathrm{~ns}$ \\
MY SNF & $\mathrm{Y}=16.48-0.002 \mathrm{x}$ & 0.000 & 0.793 & -0.89 & $* *$ \\
MY Lactose & $\mathrm{Y}=7.04-0.002 \mathrm{x}$ & 0.000 & 0.818 & -0.90 & $* *$ \\
MY Energy & $\mathrm{Y}=5.92-0.002 \mathrm{x}$ & 0.000 & 0.805 & -0.89 & $* *$ \\
BF TS & $\mathrm{Y}=16.42+0.253 \mathrm{x}$ & 0.246 & 0.096 & 0.31 & $\mathrm{~ns}$ \\
CP TS & $\mathrm{Y}=16.41+0.236 \mathrm{x}$ & 0.241 & 0.088 & 0.29 & $\mathrm{~ns}$ \\
Energy TS & $\mathrm{Y}=17.05+0.182 \mathrm{x}$ & 0.225 & 0.062 & 0.24 & $\mathrm{~ns}$ \\
Lactose TS & $\mathrm{Y}=16.03+0.396$ & 0.211 & 0.260 & 0.51 & $\mathrm{~ns}$ \\
Energy TS & $\mathrm{Y}=2.088+0.890 \mathrm{x}$ & 0.014 & 0.979 & 0.99 & $* *$ \\
CP SNF & $\mathrm{Y}=12.06+0.205 \mathrm{x}$ & 0.336 & 0.036 & 0.19 & $\mathrm{~ns}$ \\
Lactose SNF & $\mathrm{Y}=9.96+0.826 \mathrm{x}$ & 0.207 & 0.614 & 0.78 & $* *$ \\
BF CP & $\mathrm{Y}=3.92+0.145 \mathrm{x}$ & 0.320 & 0.020 & 0.14 & $\mathrm{~ns}$ \\
\hline
\end{tabular}

$\mathrm{MY}=$ Milk yield, $\mathrm{TS}=$ Total solids, $\mathrm{BF}=$ Butterfat, $\mathrm{CP}=$ Crude protein, $\mathrm{SN} \quad \mathrm{F}=$ Solid-not-fat, $* *$ Significant $(\mathrm{P}<0.01), \mathrm{ns}=$ Not significant, $\mathrm{Y}=$ Dependent variable (goat), $\mathrm{X}=$ Independent variable (rubber seed)

\section{Conclusion}

In conclusion, the investigation reveals that boiled rubber seed meal enhances milk yield in West African dwarf does. However, $10 \%$ inclusion level of BRSM that produces highest milk yield, best lactose content, and moderate butterfat composition is recommended to farmers as the inclusion level in dairy does diet.

\section{References}

Adamu, J. Y., Alemede, I. C. and Lasisi, K. T. 2010. Comparative study of body weight of savanna brown goats of different age groups raised semi-intensively in Minna, Nigeria. In: Pro. $35^{\text {th }}$ conf. Nig. 


\section{West African dwarf does fed dietary levels of boiled rubber seed meal based diets}

Soc. for Anim. Prod. 14-17. March, 2010. University of Ibadan, Nigeria, Pp 537-539.

Adebowale, A. E. and Ademosun, A. A. 1981. The carcass characteristics and chemical composition of organic and muscles of sheep and goats fed BDG based ration. h t t p / / w w w. fao .org.org /AGA/AGAP/FRE/tap62/62133.pdf.

Ahamefule, F. O. 2005. Evaluation of Pigeon Pea-Cassava Peel Based Diets for Goats Production in South-Eastern Nigeria. Ph.D. Thesis. College of Animal Science and Animal production, MOUAU, Umudike, Nigeria.

Ahamefule, F. O. Ibeawuchi, J. A. and Ejiofor, C. A. 2003. A Comparative study of the Constituents of cattle, sheep adn goat milk in a hot humid environment. Discovery and Innov. 15.64-68.

Ahamefule, F. O., Ibeawuchi, J. A. and Ibe, S. N. 2005. Performance of West African Dwarf ( W A D ) Bucks Pea Pigeon Pea-Cassava Peel Based Diets. Journal of Animal and $\mathrm{V}$ e t e r i n a r y Advances, 4(2): 1010-1015.

Ahamefule, F. O. and Odoemelam, V. U. 2006. Effect of different thermal treatments on the proximate composition, anti-nutritional properties, gross energy and mineral assay of Canavalia plagiosperma seeds. Trop.J. Anim.Sci. VO19, (2), 63-74

Amrein-Boyes, D. 2009. 200 easy Homemade Cheese Recipes. Robert Rose Inc: Toronto. American Goat Association, adga.org.

Anya, M. I. 2012. Evaluation of African Yam bean-Cassava peel meal based diets for goat's production in south- eastern Nigerian. Ph.D., Thesis, Michael Okpara University of Agriculture, Umudike.

AOAC 2000. Association of Anlytical Chemist. Official methods of Analysis $17^{\text {th }}$ Edition AOAC Ic, Arlingon, Virginia, USA.

Babatunde, G. M., Pond, W. G. and Peo, E. R. Jr. 1990. Nutritive Value of rubber seed (Hevea brasiliensis) meal: Utilization by growing pigs of semipurified Diets in which rubber seed meal partially replaced $\begin{array}{lllllll}\mathrm{s} & \mathrm{o} & \mathrm{y} & \mathrm{b} & \mathrm{e} & \mathrm{a} & \mathrm{n}\end{array}$ meal.http://digitalcommons.unl. edu/animal SciFac pub/688.

Devendra, C. 1983. Feed information and animal production processing of second symposium of the international Network of feed information centers. Pp 479-483. Slough, U.K, common wealth Agricultural Bureaux.

Duncan, D. B. 1955. New multiple Range and multiple $\mathrm{F}$ Test. Biometrics. 11:1-42.

Eneh, U. 1998. Proximate analysis of decorticated rubber seed. Research and Dev. Co; Nnewi Nigeria.

Erdman, R. A., Verner, M. 1995. Fixed Yield Responses to increased Milking Frequency. J. Dairy Sci. 1995, 78: 1199-1203.

Ibeawuchi, J. A. 1985. A study on vacation of some milk constituents of Frisian cows at Vom. Nig .j. Anim.Prod .Res. 5. (11); 113-124.

Ibeawuchi, J. A. 1995. A study on variation of some milk constitution of some milk constituents Friesian Cows at Vom. Nig. J Anim. Prod. Res. 5(11): 113-124.

Jennes, R. and Juarez. 1980. Composition and Characteristics of Goat Milk: Reviews 1968- 1999, J. Diary Sci. 63:1605-1630.

Jenness, R. 1980. Composition and 


\section{Udo, Ahamefule, Ibeawuchi and Ekpo}

characteristics of goat milk; Reviews 1968-1979, J Dairy Sci. 63; $1605-1630$

MAFF. 1984. Energy allowances and feeding system for ruminants. Second edition. Chalcombe Publications, Marlow, UK.

Marier, J. R., and Boulet, M. 1959. Direct Analysis of Lactose in milk and serum. J. Dairy Sci. 1959: 42:1370.

Mathewman, R. W. 1995. Dairying Mcmillan Tropical Agricultural Services University of Edinburgh, U.K.

McDonald, P., Edward, R. A. and Greenhalgh, J. F. D. 1994. Animal Nutrition, $4^{\text {th }}$ edn Longman Group Ltd.

Morris, T. R. 1999. Experimental Design and Analysis in Animal Sciences, CABI Publishing, Wallingford, UK. Pp. 208.

Muinga, R. W. 1995) . Topps, J.H.; Rooks J.A. and Thorpe, W. The effect of supplementation with leucaena leucocephala and maize on voluntary food intake, digestibility, live weight and milk yield of Bos indicus X Bos Taurus dairy cows and rumen fermentation in steers offerd Pennisetum purpurreum ad libitum in thr semi- humid tropics Anim.sci. (formally Anim prod), 60(1);13-24.

Njwe, R. M., Chifon, M. K. and Ntep, R. 1988. Potential of Rubber Seed as Protein Concentrate Supplement for Dwarf Sheep of Cameroon. Proceedings of the first joint workshop. Trypanotolerant livestock in West and central Africa. Volume 2 Malawi: FAO Corporate Document Repository

Nouke, L. and Endeley, H. N. 2001. Effects of incorporating rubber seed meal supplemented with blood meal in broiler rations under traditional condition. C. R. Z. Wakwa, B. P. 65, NgaoundereCamoroon. Ministyere de I'Enseignement superrieur et de la Recherche scientifigue (M. E. S. R. E. S.). pp. 33-35

Perdock H. B., Thamotheram., Blom J. J., Van-den, H. B. and Velum, V. C. 1983. Practical experiences with urea ensiled straw in Sri Lanka In: Preston T.R. Davis C. Dolberg F.M Hague M. and Saadullah M.(eds), maximum livestock production from minimum land. Proceeding of the third seminar held in Bangladesh Agricultural University, Mymonsineh; Bangladesh pp 123-134.

Polan, C. E., Herrgton, T. A., Work W. A. and Armutano, L.E. 1985. Milk Production responses to diets supplemented with browse, wet brewers grain or soya bean meal. $J$. Dairy Sci. 68:201-2026.

Prasanpanich, S., Sukpituksakul.; Tudsri, S; Milked, C.; Thwaites, C. J. and Vajrabukka, C. 2002. Milk production and eating pattern of lactating cows under grazing and indoor feeding conditions in central Thailand Trop. Grasslands 36: 107115 .

Rai, M. M. 1980. Dairy chemistry and Animal nutrition. Kalyani publishers, New Delhi.

Wikipedia 2010. the free Encydopedia. Availableat:en.m.wikipedia.org/wi ki/ Goat

Williams, T. J., Osinowo, O. A., Onadeko, S. A., Smith, O. F., James I. J., Ijeobi, $O$. N. And Onagbeson, $O$. M. 2010. Effect of Time of Milking on Milk Yield in West Afrian Dwarf goats In: Proc. $35^{\text {th }}$ Conf. Nig. Soc. for Anim. Prod. 14-17 March, 2010, University Ibadan, Nigeria Pp. 540- 
West African dwarf does fed dietary levels of boiled rubber seed meal based diets

542.

Yeong, S. W., Asyed Ali, A. and Yusit, N. 1981. The use of rubber seed meal in poultry, (the effect of rubber seed meal in layers diets). NARDI Res.

Bull. 9:92

Received: $20^{\text {th }}$ June, 2020

Accepted: $4^{\text {th }}$ October, 2020 